\title{
The impeded archipelago of Corsica and Sardinia
}

\author{
Marcel A. Farinelli \\ Independent researcher \\ marcelfarinelli@gmail.com
}

\begin{abstract}
Sardinia (Italy) and Corsica (France) are two islands divided by a strait that is 13 $\mathrm{km}$ wide. Their inhabitants have had commercial and cultural links at least since the Bronze Age, facing similar historical processes such as colonization from mainland powers during Middle Ages and a problematic assimilation within the nation-states to which the islands are nowadays associated. Nevertheless, they are generally perceived and analyzed as separate and distant islands. This is a consequence of the geopolitical context of the last three centuries, during which Corsica and Sardinia have become part of two separate states marked by a troubled relationship. This study has two main purposes: explaining the case of the two islands through a historical analysis of the island-to-island relationship between the $17^{\text {th }}$ and $21^{\text {st }}$ Centuries and proposing the concept of 'impeded archipelago' to describe analogous situations.
\end{abstract}

Keywords: archipelago, Corsica, islands, island-to-island relationship, nationalism, Sardinia

https://doi.org/10.24043/isj.142 • Received August 2020, accepted December 2020

(C) Island Studies Journal, 2021

\section{Introduction}

Few scholars have adopted an archipelagic perspective on Corsica (France) and Sardinia (Italy), albeit the strait that divides them (The Strait of Bonifacio) in its narrow point is 13 $\mathrm{km}$ wide. Sardinians and Corsicans have had economic and cultural ties at least since the Bronze Age, they experienced colonization from continental powers during Middle Ages and Modern Era, and they shared a problematic integration process in the mainland country to which they are linked with since the $18^{\text {th }}$ and $19^{\text {th }}$ Centuries. Communications between the two islands are sometimes temporarily disrupted due to strong winds blowing in the Strait of Bonifacio, but this cannot justify that they are today perceived as separate and distant. Except for the fields of natural sciences, the common approach in the humanities and social sciences fails to consider the links and common features of the two islands. This is a consequence of the geopolitical context that has marked the western Mediterranean over the last three centuries. During this period, Corsica and Sardinia have become part of two separate nationstates characterized by a troubled relationship, which has significant consequences for how the two islands are perceived. 

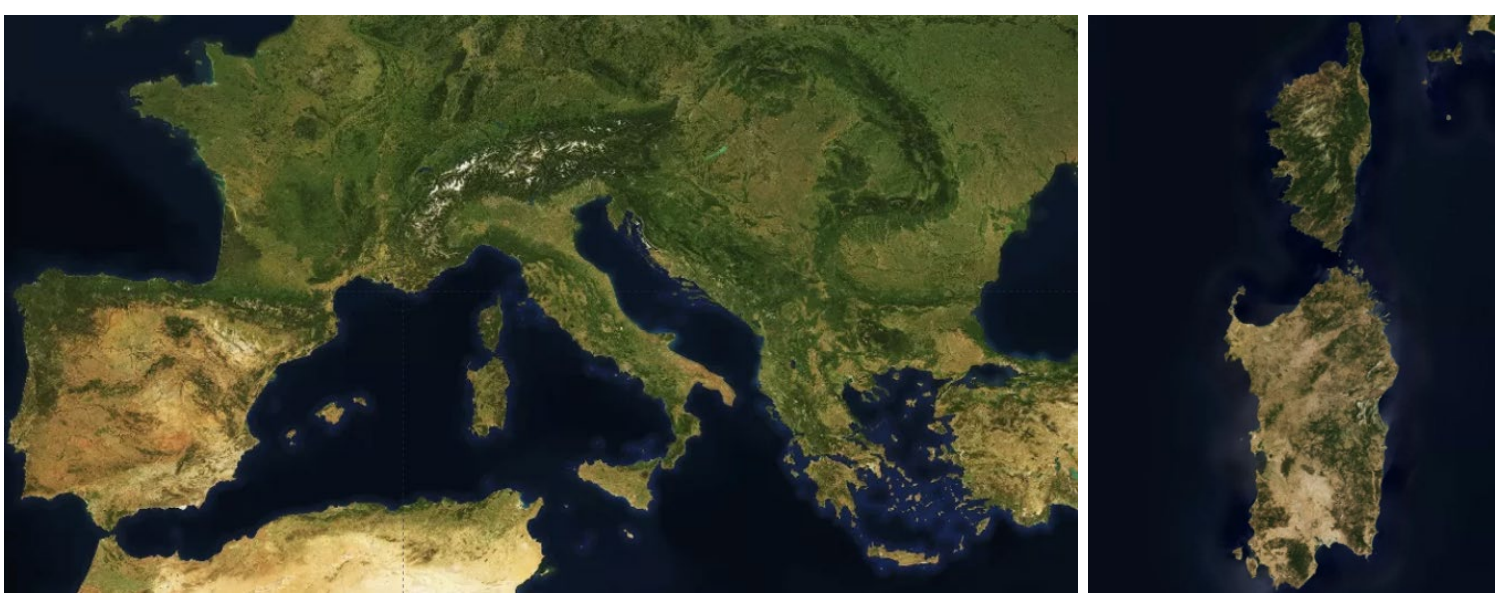

Figure 1: The Mediterranean Basin with a satellite view of Sardinia, Corsica, and their surrounding islands. Sources: Marcel A. Farinelli using Mapbox.

The two islands are not separate entities but comprise one geographical system. Taking as a reference point the appeal for the application of an archipelagic approach to the study of insularity (Stratford et al, 2011), our aim is to highlight the importance of a relational perspective focused on what Pugh (2013) calls 'island movements' rather than an isolationist or an island-continent approach (for a detailed resumé on archipelagic studies and relationality, see Pugh, 2018). This perspective was developed first by scholars working on islands and archipelagos in the Caribbean and Pacific Ocean (DeLoughrey, 2001, 2007; Hau'ofa, 1993, 2008; Pugh, 2013), with a focus on theoretical aspects or comparative literature, and recently was adopted to explore other contexts, such as the case of Sicily and the Maltese Archipelago (Camonita, 2019). These works are more concerned with conceptualizing the archipelagic perspective than with exploring the physical relations between the islands (trade, migration, transport) or island-to-island cooperation, which are the elements that make up an archipelago (relevant exceptions are Anim-Addo, 2013; Camonita, 2019; Xie et al, 2020).

Our intention is to advance further in archipelagic studies by focusing on the historical elements that create, or interrupt, the relationship between islands, preventing or making possible the archipelagic perspective. To do that, we discuss the case of Corsica and Sardinia, proposing a concept: the impeded archipelago. This is conceived as a tool able for defining a unified geographical space, albeit one that has usually been perceived and analyzed as a divided area, particularly because of the presence of national borders, geopolitical tensions, and opposing nationalisms. To achieve this goal, the article is divided in two parts: the first is a discussion of the concept of the archipelago, focused on the geographical aspect of the term rather than its metaphorical uses; the second is a description of Sardinia and Corsica as an archipelago, focusing on the elements that, from a historical point of view, have created connectedness or separation, and on how the two islands have been studied in the social sciences.

\section{What is an archipelago?}

First, it is worth clarifying that the author of this article is a historian interested in insularity in the Mediterranean who is aware of the importance of the geographical element in historical research and, more generally, in the humanities. In this regard, the perspective adopted in this 
paper is influenced by the suggestion that Fernand Braudel made in his analysis of the Mediterranean. The French historian urged considering transnational areas, rather than by being bound by the divisions imposed by state borders (Braudel, 1953). From this point of view, the analysis begins with a basic question: what is an archipelago? The word was used for the first time in classic Greek and developed to its present meaning through medieval Italian. A comparison between the definition of the word according to different language sources reveals a lack of consensus on its meaning. For one of the most important dictionaries of modern Italian, edited by the Enciclopedia Treccani (n.d.), the definition is "a grouping of islands sparse at sea but sufficiently near among them, and sometimes with similar morphological characteristics." But, according to the online version of the Cambridge Dictionary (n.d.), an archipelago is "a group of small islands or an area of sea in which there are many small islands." However, if we check the New Oxford Dictionary of English (2001), the definition is a little different: "a group of islands" or "a sea or stretch of water with many islands." Finally, in French, accordingly to Dictionnaire Larousse (n.d.), an archipelago is "an aggregate of islands on a maritime surface more or less extended."

Such difficulties in finding a precise definition of the word are similar to the problems experienced in defining what is an island, as shown by Royle and Brinklow (2018). However, relative to the word 'island', the concept of archipelago is less accurate and more arbitrary, and results from a mental process by which islands are bonded together. First, the meaning of the word depends more on human perception than on any sense of objectivist geography, as noticed by many scholars (Hayward, 2012; Lee et al., 2017; Stratford et al., 2011). Second, grouping islands is an act of will: "an archipelago is only an archipelago if we decide to gather islands together into it" (Xie et al., 2020, p. 13). Thus, an archipelago is the result of a human process, through which some islands that occupy a contiguous marine space are assembled, for cultural, political, economic or historical reasons, and considered as a homogeneous group. Why do we separate the Bismarck Archipelago from the Solomon Islands? What are the criteria applied to consider the Dodecanese as one group of islands, while the Cyclades are defined as an archipelago apart? Such assemblages are a kind of arbitrary classification that, above all with islands divided between different nation-states or colonial powers, has an important epistemological consequence. It prevents us from adequately considering the interinsular connection, making the linkage between two or more politically separated islands invisible to their geographical and historical context.

\section{The impeded archipelago}

As we have seen, an archipelago is the result of a conceptual assemblage rather than a geographical element that can be detected and described with accuracy. Linkage is as important as distance in enabling us to define a group of islands as an archipelago, though "assemblages are never stable because they are effects of force relations brought into relation with one another in particular ways, which can always potentially be reconfigured in different ways" (Pugh, 2016, p. 1043). Therefore, what happens when two (or more) islands are close, but there are no connections, or those that exist are scarce, inconstant, impeded or invisible? What happens when historical evolution impedes existing relations between a group of neighboring islands previously assembled? Should the obstacles to the linkage, whatever the source, be a reason for preventing us from defining these neighboring islands as an archipelago? 
A solution to that problem was proposed by Camonita (2019), through a classification of island-to-island relations based on Braudel's (1958) theory of longue durée. The author analyzes Sicilian-Maltese relations from 5000 BCE until 2018, pointing out the existence of movements of connection and separation throughout this period that resulted in an irregular relationship between the islands considered: Sicily (with its nearby Aegadian, Aeolian, and Pelagian Islands) and the Maltese Archipelago (Camonita, 2019). The author fails to define the area as an archipelago or to propose an alternative definition, but his schematic analysis of island movements provides a way of envisioning the Sicilian-Maltese archipelago (or at least the island-to-island relation) on the longue durée. Considering such a long period, it is impossible to provide more historical details about the processes that assembled/disassembled the islands. For this reason, our own case study considers a shorter lapse of time $\left(17^{\text {th }}-21^{\text {st }}\right.$ Centuries), during which island-to-island relations have been created and progressively interrupted, and the islands studied are closer and more similar in size. In this way, we can describe the process of connection and separation in detail, focusing on the elements that created, or interrupted, island-to-island relationships. Our intention is therefore to further develop the work of Camonita (2019), proposing a definition for this kind of island group and providing a historical analysis of the island movements between Corsica and Sardinia since the $17^{\text {th }}$ Century.

From a historian's perspective, for carrying out such analysis is important to have an element that allows us to assemble islands separated for political reasons into an archipelagic historical narrative. An example is the work of F.W. Knight (1990), who conceived of the Caribbean as a fragmented archipelago using colonialism, decolonization, and the rise of island nationalisms as unifying elements of his narrative. Geography alone cannot be such a unifying element because the existence of the relationship, or the absence of it, depends on human factors, such as trade, transport, and the movement of people from one island to another. Without connection, the concept of archipelago is inappropriate and a more generic definition such as 'group of islands' should be used. But the sense of unity recalled in this expression could be misleading in trying to define some adjacent islands with a problematic relationship, or with no relationship at all. For all these reasons, we propose the concept of impeded archipelago, defined as a group of islands that are sufficiently close to each other to be interlinked and perceived as a group, that share geographical and cultural elements and have a common historical development, but which, for political and historical reasons, are divided (or perceived and analyzed as such). This concept allows the analysis of island-to-island relations and of the absence, impediment, or interruption of these relations.

This theoretical and interpretative model is based on our experience in investigating the modern and contemporary history of Corsica and Sardinia. The two islands are close enough to be defined as an archipelago but, despite the willingness showed by their inhabitants at certain moments of their history, they have a problematic relationship. Here the archipelago is impeded mostly by external factors, such as national boundaries and geopolitical tensions, and the concept could apply to other cases, such as the aforementioned example of Sicily and the Maltese Archipelago. However, not all archipelagos are impeded by external forces. Sometimes, there is a precise willingness not to be bonded with a neighboring island, for economic, cultural, or social reasons. This is the situation of an archipelago impeded not by national boundaries and international tensions, but by intraarchipelago dividing forces, as is the case for Aruba, Bonaire, and Curaçao. The three are 
considered an island group within the Leeward Antilles archipelago, informally known as the 'ABC Islands'; they are all part of the Kingdom of the Netherlands and share a common past. Despite this, the relationship between them is tense, resulting in the political fragmentation of the group into three separate entities: Aruba and Curaçao are autonomous countries of the Kingdom of the Netherlands, while Bonaire is a special municipality (Oostindie, 2006; Veenendaal, 2015).

\section{Corsica and Sardinia: A troubled relationship}

In the case analyzed here, the non-achievement of the archipelago is a consequence of political geography. A borderline runs across the Strait of Bonifacio, and this has profoundly influenced our perception of this space. Above all, it has determined the perspectives adopted by the scholars from different disciplines of the humanities and social sciences who have addressed these islands. Since the pioneering work of Fredrik Barth (1969), borders, boundaries, and the notion of 'the frontier' have been the subject of discussion, with many authors pointing out the importance of borderline areas for the evolution of nationalism and the definition of national identities (Donnan \& Wilson, 2001; Hylland Eriksen, 1992; Sahlins, 1989). However, there is no published analysis of the Sardinia-Corsica space as a border area.

There is evidence that a link existed between the islands at least since the $2^{\text {nd }}$ Millennium BCE, as the Nuragic (Sardinia) and Torrean (Corsica) civilizations have such similar characteristics that they are supposed to be a single civilization (Camps, 1988; D'Anna, 2007; Lilliu, 1987). Sardinia was then colonized by the Phoenician-Carthaginians, and Corsica by the Greeks, until the Romans conquered the two islands in 238-236 BCE, merging them into a single province (Mastino, 2005; Pais, 1923). This was the only historical period when the two islands were successfully united under the same administrative unit, but it is during the Middle Ages that we can identify the origins of some common characteristics that marked present-day Corsica and Sardinia. Around the $11^{\text {th }}$ Century, they were disputed between the Italian city-states of Genoa and Pisa and local sovereign entities: four kingdoms in Sardinia (called Judicados in Sardinian), feudal lords, and rural communes in Corsica. Both islands were formally a fiefdom of the Papacy, therefore in 1297, Pope Boniface VIII, trying to exclude Italian city-states and to solve the dispute around the sovereignty of Sicily (also a papal fiefdom), proclaimed the Kingdom of Corsica and Sardinia, giving its sovereignty to the Crown of Aragon. The kingdom was never achieved, and eventually, around the end of the $15^{\text {th }}$ Century, Genoa controlled Corsica, while Sardinia became part of the Spanish Empire. This situation lasted until the $18^{\text {th }}$ Century when, after 40 years of anti-Genoese revolt (17291769), Corsica was handed to the Kingdom of France, and Sardinia, as a consequence of the War of the Spanish Succession (1701-1714), was given to the House of Savoy (see Arrighi \& Jehasse, 2013; Brigaglia, 1998).

Despite the troubled political circumstances that divided the two islands during the Middle Ages, the Strait of Bonifacio remained permeable until $19^{\text {th }}$ Century. In the late $17^{\text {th }}$ Century, Corsicans settled on the islets of La Maddalena, Caprera, and Santa Maria, then called Isole Intermedie (Racheli, 1982, pp. 136-154). From here, they moved into northern Sardinia, maintaining a link with Corsica through legal commerce and smuggling, and reproducing some practices originating in their homeland. The presence of the Corsican population has resulted in a strong difference between this area (called Gallura) and the rest of Sardinia, as 
demonstrated by the type of rural settlement (the Stazzo) - resulting in a very distinctive landscape - and the language spoken (Gallurese). Both elements are of Corsican origin but are nevertheless deemed part of Sardinian cultural heritage (Maxia, 2008; Piredda, 1997).

The case of the Corsicans settled in La Maddalena, Caprera, and Santa Maria is highly relevant for our discussion. They maintained a close relationship with Bonifacio in Corsica, but also developed links with Sardinia. The group of small islets was not considered in any international treaty, so it was unclear whether it belonged to the Kingdom of Sardinia or the Republic of Genoa. In this way, the inhabitants of the three small islands lived between the two jurisdictions, residing on the islets from autumn to spring whilst smuggling cattle from Sardinia to Corsica. During summer they moved to Bonifacio, where they carried out the legal activities, i.e., baptizing children, celebrating weddings, and selling goods and livestock (Pira, 1994; Sole, 1955-1956). In 1767, the King of Sardinia, worried about the involvement of French troops in the suppression of the anti-Genoese uprising in Corsica, established sovereignty over the islets closest to the Sardinian shore (Sole, 1959). Links with Bonifacio were progressively interrupted, and Sardinian authorities improved their control over the area, building the town of La Maddalena and placing a naval facility there. Corsicans continued to smuggle Sardinian products to Bonifacio, and fugitives of both islands used to cross the Strait to escape justice. The presence of many islets and small inlets made coastal surveillance a very hard task, and the situation did not change much later, in 1807, when the King of Sardinia built the town of Santa Teresa Gallura just in front of Bonifacio (Murgia, 1988, 1994).

The border began to be less permeable with the proclamation of the Kingdom of Italy (1861). After France imposed the protectorate on Tunisia (1881), a territory claimed by Italy, Franco-Italian relations turned tense until the end of World War II (see Bertrand et al., 2016; Chabod, 1951; Shorrock, 1983). During this period, Italian nationalists claimed Corsica as one of the 'unredeemed lands', an expression used to identify those territories not annexed during the unification process of 1859-1861. Irredentism was one of the driving forces of Italian foreign policy, leading to a progressive deterioration of the relationships with France. Tensions between the two countries reached their apex during the governments of Francesco Crispi (1887-1891; 1893-1896), who declared an economic war against France, and especially during Fascism (1922-1945). Benito Mussolini considered Corsica an important steppingstone for achieving the main objective of his foreign policy, a Mediterranean empire, and eventually occupied the island during 1942-1943 (Giglioli, 2001; Paci, 2015; Rainero, 2005).

As citizens of neighboring and rival nation-states, Corsicans and Sardinians have been subjected to a process of nationalization and identity-building, in which the definition of the national borderline is a fundamental feature. The Strait changed from a cultural and material contact area to a militarized frontier, and the border became a mental one, as suggested by Kearney (1991), able to divide the islanders according to the opposed national identity of Corsicans and Sardinians. In 1887, the naval facilities of La Maddalena were reinforced and extended to the islet of Santo Stefano, turning them into an important base for the Italian Navy. During Fascism, the fortifications extended along the entire coastline in front of Corsica and, in response, the surroundings of Bonifacio were heavily fortified.

The relationship between Italy and France improved after World War II, and an increasing number of Sardinians moved to Corsica in search of work, but the border remained problematic for a variety of reasons, among them, island nationalism. Sub-state nationalist parties had appeared on both islands in 1921-1922, and there was a connection between them 
to the point that they had almost the same name: Corsican Action Party and Sardinian Action Party (Farinelli, 2020; Roux, 2012). During the 1960s and 1970s, Corsican nationalism became radicalized and was perceived by part of the French public opinion as connected to Italian irredentism (Crettiez, 1999; de la Calle \& Fazi, 2010). Sardinian nationalism, by contrast, has always been characterized as moderate, especially after autonomy was achieved in 1948. Nevertheless, after the mid-1960s, part of it became more radical, campaigning for full independence (Clark, 1996; Hepburn, 2009). For this reason, the Italians were worried that the radicalization of the Corsican nationalists would end up having consequences for the Sardinians, while French governments were concerned that the economic development achieved by Sardinia since the island had obtained the status of a sub-national island jurisdiction (SNIJ) would strengthen criticism of the centralized governance model adopted by Paris in Corsica (Farinelli, 2020).

This led to an unfavorable context for the development of the collaboration between Corsican and Sardinian local authorities. Despite this unfavorable context, between 1950s and late 1960s several attempts were made to establish cooperation between the two islands. The first step came from the Sardinian entrepreneurial sector's willingness to develop an economic relationship with the neighboring island. The idea, outlined by a foremost Sardinian economist, Gavino Alivia (1954), was to integrate the two economies to overcome underdevelopment and reduce the problems derived from insularity. Alivia pointed out that Sardinia needed water for agriculture and energy for its plan of industrialization, while Corsica had a large reserve of water but reduced agricultural production and no factories. Therefore, Corsicans could build power plants to sell electricity to Sardinians, in exchange for agricultural and manufactured products. Moreover, with better island-to-island connections it would be easier to connect Cagliari with Italy, and Bastia with Algiers, while Corsica and Sardinia would become a single touristic destination (Alivia, 1954). In 1955, the French and Italian governments signed an agreement to permit tourists to cross the Strait of Bonifacio with a special eight-day pass, and communications substantially improved.

During the following years, contacts between Sardinian regional governments and Corsican local authorities increased, and a Corsican-Sardinian commission was even proposed to boost the relationship between the two islands. Nevertheless, French prefects in Corsica were worried about Sardinia's competitiveness in the touristic sector (lower prices, specialized workers, more hotel rooms), and feared weakening economic ties with the French mainland. In a context marked by the growth of nationalism, French authorities in Corsica discouraged implementation of the relationship with Sardinia (Le Préfet, 1965; Pigoreau \& Ditrie, 1965). At the same time, Corsican entrepreneurs proved reluctant to improve the relations, although they occasionally met with Sardinian counterparts to strike economic deals (Le Préfet, 1968). Eventually, the commission failed to meet, and Corsican-Sardinian relations stalled in mid1970s, except for some sporadic cases of trade (CCIASS, 1968-1972).

Other attempts to improve the island-to-island relationships were made after Corsica obtained the SNIJ status in 1982. This included not just economic relations, but also cooperation between the universities of the two islands, though political unrest in Corsica continued to prevent a fluent relationship. Italian intelligence agencies monitored the contacts between Corsican and Sardinian nationalists (SISDE, 1983), and in 1989 a memorandum of a highranking French civil servant, then in part adopted, suggested avoiding trade with Sardinia to protect the Corsican market and promote agriculture (Prada, 1989). Since the 1990s, 
economic relations and inter-insular collaboration have improved thanks to the development of European institutions and the cross-border cooperation programs, called Interreg (Biggi, 2001; Olivesi, 1999). These programs financed infrastructures to better connect the two islands and to improve cultural contacts, trade, and collaboration in aspects such as environmental protection. Since the 1950s, the relationship between the two islands has been growing constantly, as shown by the traffic between the ports of Bonifacio and Santa Teresa Gallura. Between 1954 and 2018, the total amount of goods crossing the Strait of Bonifacio increased from 64 tons to 18,922 tons, while the number of passengers increased from 1,363 to 274,177 (author's elaboration using data records from the Chamber of commerce of Ajaccio [CCIAAS, 1981-1993], Sassari [CCIASS n.d.], and statistics from Regione Autonoma della Sardegna [RAS; 1954-1968], INTERREG Marittimo-IT FR-Marittime and Autorità di Sistema Portuale [ASP; 2017, 2018]). Trade increased particularly since the 1990s, but cooperation between the governments of the two islands remained weak, and in 2016 a memorandum of understanding was signed to strengthen collaboration in the fields of transport, education, and economy (Mari, 2016; Regione Autonoma della Sardegna [RAS], 2016).

Highly significant for the difficulties of Corsican-Sardinian relations are the cases of IMEDOC and of the International Marine Park of the Strait of Bonifacio. IMEDOC is the acronym for Îles de la Méditerranée Occidental, a lobby formed by the SNIJs of Corsica, Sardinia, and Balearic Islands and founded in 1995 under proposal of the President of the Autonomous Community of the Balearic Islands. The idea was to lobby European institutions to obtain special policies addressed to island regions, and to foster cooperation, cultural relations, and trade. In the beginning, it was considered an important tool for inter-insular cooperation (BérnabeuCasanova, 2001; Biggi, 2001), nevertheless IMEDOC results have been limited to the publication of some academic and non-academic books, and the celebration of cultural meetings.

The French and Italian governments proposed the International Marine Park in 1993 after Sardinian and Corsican civic organizations and nationalist parties campaigned to ban cargo ships from crossing the Strait of Bonifacio. Such a prohibition is impossible due to conventions on navigation, which prevent any restriction on navigation in international straits, so the park was intended as a means of limiting pollution in a very vulnerable area. But it was so innovative that the proposal proved hard to achieve. Between 1994 and 1999, both countries, under the auspices of the first Interreg program, each established a nature reserve on their sides of the Strait. The problem was in determining how to merge the two reserves and how to manage a structure that extends across borders and is subject to different legislative systems. The solution arrived by the European institutions, which in 2007 established the European Group of Transnational Cooperation (EGTC), an administrative tool to develop the Interreg programs. Between 2010 and 2012, an EGTC was formed to manage the park, consisting of a committee of members named by the two authorities in charge of the respective national parks. Unfortunately, a series of problems, including bureaucracy, tensions among local administrations, and the receivership of the Archipelago di La Maddalena National Park between 2016 and 2018 (La Nuova Sardegna, 2013, 2016), have prevented EGTC from functioning properly. Today, the International Marine Park of La Maddalena exists as two separate national parks, but the problem of how to overcome the different national legislations and manage the area as a single park remains.

The consequences of this maritime frontier go beyond the troubled relations outlined above. They have affected research on the two islands and, consequently, their perception. 
Until 1945, there was an abundance of studies, by both Italian and Corsican authors, which emphasized the links between Corsica and Italy. Most of these studies aimed at claiming Corsica as an Italian island, and therefore, although they could refer to specific elements, they had an obvious propaganda purpose (Paci, 2014). Among the more prominent examples, some studies cited the geological continuity between Sardinia, Corsica, and Tuscany (Vardabasso, 1939), while others, such as the linguistic research of Gino Bottiglioni (19391952), underlined similarities between some variants of the Sardinian language, Corsican, and Tuscan. This research did not aim to explore island-to-island relationships, but attempted to show that Corsica was part of Italy. However well-researched, the irredentist purpose of such publications ended up preventing any archipelagic approach to the study of Corsica and Sardinia, as it would have been interpreted as mere propaganda. The French, for their part, opposed the Italian claims by emphasizing every element of connection between Corsica and mainland France, with arguments that included the interpretation of the short period during which the island was under French rule (1553-1559) as a time when a strong link was established; the participation of Corsicans mercenaries in the French Army, especially in the Royal-Corse regiment, as evidence that the Corsicans wanted to join France; and the presentation of the French involvement in the island as motivated by the willingness to free the Corsicans from the oppression of Genoa (for an example of such literature, see the classical work of Rombaldi [1887]).

Because of that cultural clash - a symptom of the French-Italian rivalry in the Mediterranean-after World War II, the relationship between Corsica and Sardinia was substantially taboo. The most relevant historical analysis considering Corsica and Sardinia as a whole remained a history of the Roman province of Corsica and Sardinia (Pais, 1923). For the French side, the prominent historian Fernand Braudel, who claimed to overcome the fictitious division of the geographical space caused by frontiers, failed to escape the nationalist paradigm he operated within. In fact, he felt obliged to reaffirm the bond that existed, in the $16^{\text {th }}$ Century, between Corsica and the Kingdom of France, labelling the Italian studies that showed inter-island contact or the links with the Italian peninsula as irredentist propaganda (Braudel, 1953, Vol. I, pp. 139-140).

In history and in the social sciences, the two islands have been largely analyzed as discrete compartments. National division, irredentism, construction of the border, and geopolitical tensions are all elements that have produced the perception of a divided area. This separation is, however, highly arbitrary for several reasons. Geographical evidence suggests that the two islands are in fact a single system. The presence of mountain reliefs that occupy the central part of both islands, the diffusion of an economic system (and therefore of a land use, based on semi-nomadic animal husbandry; Le Lannou, 1941; Ravis-Giordani, 1983), and the existence of similar linguistic and cultural elements are components that unite Corsica and Sardinia, even if they are not entirely identical. But most important is the historical development that enables us to consider the two islands as a system, providing the cultural elements and economic processes that produce an archipelagic space around them. Although attempts to develop economic, cultural, and political ties between Corsica and Sardinia have largely failed, the similarities of their historical evolution demonstrates the existence of an archipelago, impeded. 


\section{The archipelagic dynamic}

The assertion that Corsica and Sardinia have substantial physical, social, and cultural elements in common reflects the metamorphic aspects of their seriality (as suggested by Jonathan Pugh (2013) regarding the Caribbean islands), rather than similitude. Pugh's argument (2013) referred to metamorphosis as a way of adapting elements of African or European culture to the Caribbean context, in contrast to repetition/imitation. Here, the concept of metamorphosis is used to explain the existence of similar phenomena in the two islands of Corsica and Sardinia, which, however, both adopt peculiar characteristics. Some examples of these shifting elements are the Corsican language spoken in north Sardinia, and the cultural influence exercised by the maritime powers that dominated the coastlines before French and Italian nation-building processes began. The former is a consequence of migration-although the Corsican spoken in north Sardinia is not exactly the same language as that used in Corsica-whilst the latter results from history and geography: the war to conquer the islands led to the establishment of fortified cities on the coast entirely settled by mainlanders, where the language and cultural habits of the colonizers are still detectable.

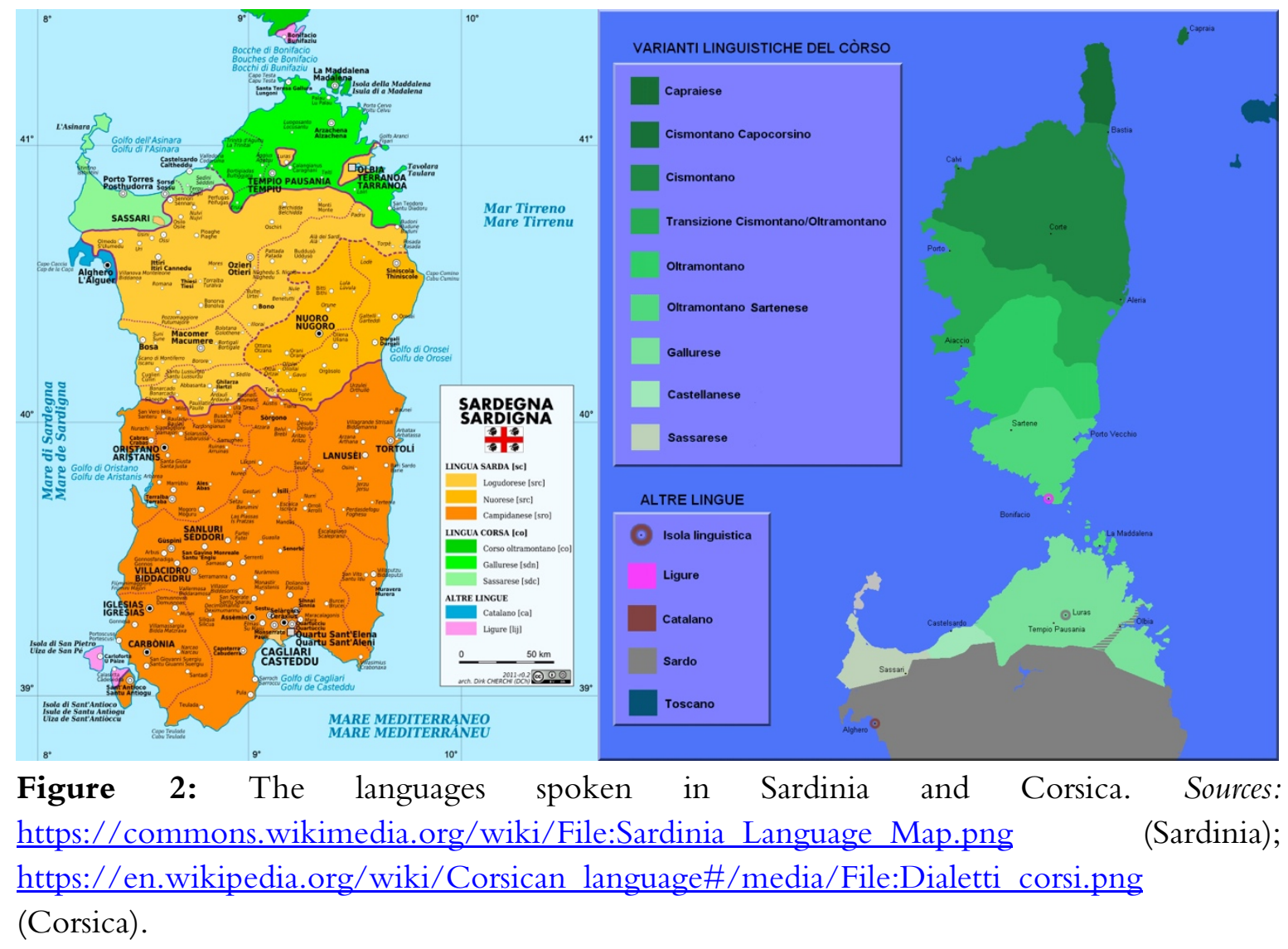

Underlying these variations is a common historical dynamic. Generally, the key shared aspect is the conflictual relationship existing between the colonized shores and inaccessible internal regions of both islands (Lopasic, 2001, p. 364). Spatial duality is evident in the urban phenomenon. All the islands' cities are on the coast, while the inland areas are characterized by small and medium agglomerations. The only exception is Sassari, in Sardinia, a residential center of landowners and administrative headquarters located some $15 \mathrm{~km}$ from the sea. Such 
a situation shows how since the Middle Ages there has been a strongly contrasting relationship that explains many of the features that marked the development of the two islands. In this context, the historical dynamic is characterized by spatial opposition, which corresponds to an opposition between 'natives' and foreigners. The common thread is the succession of mainland-based maritime powers ruling the islands, and the consequent resistance of the islanders to such domination. Some authors argued that this has been a key factor in historical development of Sardinia and Corsica since the Bronze Age, or even earlier (Carrington, 1971; Lilliu, 1971; Lopasic, 2001).

There is no doubt that the two islands were invaded several times, but our current analysis focuses on a shorter period of time. Between $11^{\text {th }}$ and $15^{\text {th }}$ Centuries, maritime powers such as Pisa, Genoa, and the Crown of Aragon were interested in controlling key areas of the coastlines of Corsica and Sardinia. This dispute defined a dichotomy between the coast and the interior that has marked the development of both islands' societies until the present. On the coasts, in areas where it was possible to find both a safe landing place and a good connection with the interior, colonial cities arose. Protected by powerful walls and often forbidden to the islanders, who were considered to live 'beyond the pale', these cities were centers through which maritime mainland powers could control the territory and its resources. Here lived the merchants, the military, and the administrative staff. Such places were more connected to the colonists' home countries than to the villages of the interior. Cities of this type included Alghero in Sardinia and Bonifacio in Corsica. As functional fortresses, these were so self-contained that even today part of the populations of both each use a language left by the ancient rulers-Catalans in the first case and Genoese in the second-who abandoned them in the $18^{\text {th }}$ Century (Bosch, 2002; Toso, 2008).

Another key aspect is the presence of different and opposed nationalisms, which developed during the nation-building process. Corsica officially became French in 1790, while Sardinia was ruled by the House of Savoy from 1720, enabling Vittorio Emanuele II to proclaim himself king of Italy in 1861 (formally it was the Kingdom of Sardinia conquering Sicily and the Italian Peninsula). In both cases, some symbolic and rhetorical elements of insular origin played an important role in the making of both the French and the Italian national identities (Farinelli, 2017). Alongside state nationalisms, however, there are also island nationalisms, which postulate a break-off or a change in the relationship with the mainland, and, to further complicate matters, we must consider also irredentism.

The dynamic we are setting forth here corresponds to a "characteristic set of tensions and ambiguities, opportunities, and constraints arising from the interplay of geography and history," suggested by Warrington and Milne (2018, p. 175) as a way to understand islandness. According to the model of island governance they proposed, Corsica and Sardinia can be described as a combination of settlement and fief islands; both received many settlers in the coastal towns and were exploited by external powers and their own elites. As a result, their inhabitants can exhibit three distinct identities: the islander, the mainlander, and the irredentist. The latter remains latent in the case of Corsica (Italian identity), or is only possible locally in that of Alghero (Catalan identity).

This intricate game, which is repeated in different ways on both islands, is an element that unites them in a historical dynamic that has determined their political and cultural evolution. The major consequence of this is the existence of divergent and opposing (nationalist) narratives of the past, corresponding to a pattern based on the spatial relations 
established by the subordination of the islands to mainland powers. In fact, every narrative is accompanied by a precise conception of the island territory. For state nationalisms, the privileged place is the coast, where port cities and government offices are located and to which the interior is opposed as a problematic area. The position for the island nationalisms is quite the opposite: the authentic island identity would be in inland and mountainous areas, where, protected from external influences, the real island culture would have survived. These are areas, such as the Barbagia in Sardinia or the surroundings of Corte in Corsica, where the inhabitants have repeatedly opposed state institutions. Regarding irredentism, the discourse is more complex: while the Italian mythicizes, above all, the hinterland of Corsica as an area where Italianness is uncorrupted by Francization, the Catalan only refers to Alghero as the seat of Catalanness. Both nationalisms, insular and continental (whether state or irredentist), are based on this coastline-inland spatial opposition. While for the former, the interior is the place where identity has survived in its most authentic form, for the latter, the cities on the coast are the places where civilization can be appreciated in terms of its connection to national and mainland culture.

As we have seen, the evolution of this geographical space responds to the same pattern that, since the $11^{\text {th }}$ Century, has defined areas in which different and opposed cultural and linguistic traditions have accumulated as reflections of the presence of opposing thalassocracies. This complex past is the basis for the construction of three different national narratives, which historiography has established since Romanticism. Depending on which nation is the protagonist of the story, episodes or figures can be interpreted differently, as exemplified by two historical figures: Pasquale Paoli and Eleonora d'Arborea.

Paoli was the leader of the last phase of the Corsican revolt against Genoa that gave the Kingdom of France the opportunity to invade the island (formally, to crush the revolt for Genoa) and subsequently annex it. Paoli, who ruled the island between 1755-1769, was mythologized by both Corsican and Italian nationalists and, to a lesser extent, by the French. While for the Corsicans, he is the father of the nation, for the Italians, he was a predecessor of the Risorgimento (unification of Italy) and, thus, the first of the Italian patriots. From the French point of view, even if hastily, Paoli pioneered the fight against despotism represented by the 1789 revolution. Eleonora d'Arborea too, at the head of the Judicado of Arborea (a native Sardinian kingdom) between the $14^{\text {th }}$ and the $15^{\text {th }}$ Centuries, represents a national icon that lends itself to divergent interpretations. Regarded as the leader of resistance to the Catalan invasion, she also compiled the collection of the fundamental laws of the Kingdom, which remained in force until 1848 and, for this, she is considered as a Sardinian national heroine. However, from the Italian point of view, Eleonora is perceived as a monarch who defended the Italian character of the island. Furthermore, she represents a problematic memory for Catalan nationalists, being strongly linked with the Catalan aristocracy at the same time as she was a strenuous opponent of the conquest of the island by the Crown of Aragon. As this complex game of interpretations of the past suggests, island-to-island relations have been difficult to extricate from more complex enmeshing with the power dynamics of regional colonial powers.

\section{Conclusions}

The case presented here shows how, in a maritime frontier area comprising a system of islands that, besides being relatively close to each other, have similar physical, human, and historical 
characteristics, it is difficult to consider these islands as part of a single archipelago. Nationbuilding processes which led to the formation of a border between Corsica and Sardinia and, no less importantly, triggered the development of opposing nationalisms, had among its repercussions the establishment of an illusory distance between the two islands, as if they were hundreds of nautical miles away from each other. The archipelago is not therefore just indiscernible to the external observer, but envisioning the archipelago is hard for the inhabitants of the islands too, because of established narratives, strong center-periphery dynamics, and the network of transport that links any island to its relative mainland. This enables only a minority of Corsicans and Sardinians to have an actual archipelagic experience.

But island-to-island relationships existed before the nation-building processes of Italy and France prevented the assemblage that 'makes' the archipelago. After that, there was a progressive separation of Sardinia and Corsica. The process started in the second half of the $18^{\text {th }}$ Century, when the Kingdom of Sardinia occupied some small islands in the Strait of Bonifacio, but experienced an acceleration after 1861, when the Kingdom of Italy was established, and above all between 1881 and 1945, when Franco-Italian relationships were conflictive. After World War II, Sardinian and Corsican institutions tried to build economic and political links and to establish island-to-island cooperation. But a fluent relationship was never fulfilled and, despite the increase in trade, problems remained: rivalry in the tourist industry and reluctance by the French governments were the principal obstacles to a more efficient collaboration. The implementation of the Corsican-Sardinian relationships was not an important point in the political agenda of the two island governments until a coalition of Corsican nationalist forces won the elections in 2015. During the following years, some agreements were signed to improve cooperation in culture, transport, economy, and protection of the environment. The accords were promoted by the Corsican government and welcomed by Sardinia, both conceiving them as a historical moment in the evolution of relationship between the two islands. Between 2015 and 2020, Sardinian and Corsican authorities worked on implementing this agreement, but the outbreak of COVID-19 pandemic has led this process to stall.

Evidently, the separation described in this article is arbitrary, and the willingness for establishing inter-island relationships showed by Sardinians and Corsicans has encountered resistance, both inside and outside the islands. But the relationship, although hindered by several factors, existed, continues to exist, and could improve. This is an impeded archipelago.

\section{Acknowledgments}

This paper is an outcome of the project Destructuring and restructuring the relationship between Corsica and Sardinia (1861-2018) funded by the Università di Corsica - Pasquale Paoli and the Collettività di Corsica for the year 2019. I wish to thanks Andrè Fazi who gave me the chance to spend one year researching the relation between the two islands and the staff of research unit UMR 6240 Lisa of the Università di Corsica for the support. A special thanks to Philip J. Hayward for his precious comments to an early version of this paper, to Adam Grydehøj, Ping Su, and the anonymous reviewers for their work, and for being patient with my selftaught English. 


\section{Acronyms}

ACS: Archivio Centrale dello Stato.

AN: Archives Nationales.

ADCS: Archives Departementales de la Corse du Sud.

ASCCIASS: Archivio Storico della Camera di Commercio e Artigianato di Sassari (Sardinia). ASP: Autorità di Sistema Portuale.

CCIAS: Chambre de Commerce et d'Industrie d'Ajaccio-Sàrtene (Corsica).

RAS: Regione Autonoma della Sardegna.

SISDE: Servizio per le Informazioni e la Sicurezza Democratica.

\section{References}

Alivia, G. (as Oeconomicus). (1954, May 26). L'unione economica sardo-corsa. La Nuova Sardegna.

Anim-Addo, A. (2013). Nineteenth-century maritime networks and the Caribbean archipelago. Island Studies Journal, 8(1), 25-38.

Arrighi, J-M., \& Jehasse, O. (2013). Historie de la Corse et des Corses. Perrin.

Autorità di Sistema Portuale (ASP). (2018). Movimenti Portuali-Anno 2018.

Autorità di Sistema Portuale (ASP). (2017). Movimenti Portuali-Anno 2017.

Barth, F. (1969). Ethnic groups and boundaries: The social organization of culture difference. Universitetsforlaget.

Bérnabeu-Casanova, E. (2001). Une «destin corso-sarde» dans le cadre de l'Union Européene? Herodote, 103, 152-174.

Bertrand, G., Frétigné, J.-Y, \& Giacone, A. (2016). La France et l'Italie. Histoire de deux nations soeurs. Armand Collin.

Biggi, M. (2001). La coopération interrégionale et les îles de la Méditerranée. Confluences Méditerranée, 36(1), 125-134.

Bosch, A. (2002). El català de l'Alguer. EAM.

Bottiglioni, G. (1932-1952). Atlante linguistico etnografico italiano della Corsica. Stabilimento Tipografico dell'Italia Dialettale.

Braudel F. (1958). Histoire et ciences sociales: la longue durèe. Débats et Combats, 13(4), 725753.

Braudel, F. (1953 [1949]). El Mediterraneo y el mundo mediterraneo en la època de Felipe II. Fondo de Cultura Económica.

Brigaglia, M. (1998). Storia della Sardegna. Edizioni della Torre.

Cambridge Dictionary. (n.d.). Archipelago. English Dictionary. https://dictionary.cambridge.org/dictionary/english/archipelago?q=Archipelago.

Camonita, F.M. (2019). Envisioning the Sicilian-Maltese archipelago: A Braudelian inspired triple level analysis of European cross-border region. Island Studies Journal, 14(1), 125146. https://doi.org/10.24043/isj. 82

Camps, G. (1988). Préhistoire d'une île: Les origins de la Corse. Éditions Errance.

Carrington, D. (1971). The granite island: A portrait of Corsica. Longman.

CCIAS (1981-1993). [Statistical data on goods and passengers movements in Bonifacio, Corsica]. 3 ETP 74, 75, 81, 82 and 83, ADCS, Ajaccio, Corsica. 
CCIAS (1954-1972). Rapporti economici tra la Sardegna e la Corsica [Miscellaneous documentation on the economic relation between Sardinia and Corsica]. Comunicazioni tra la Sardegna e la Corsica (busta 11, fascicolo 23), ASCCIASS, Sassari, Sardinia.

CCIASS (1968-1972). Rapporti economici tra la Corsica e la Sardegna [Miscellaneous documentation on the economic relation between Sardinia and Corsica]. Rapporti economici tra la Sardegna e la Corsica (busta 11, fascicolo 23), ASCCIASS, Sassari, Sardinia.

Chabod, F. (1951). Storia della politica estera italiana dal 1870 al 1896: le premesse. Bari:

Laterza.

Clark, M. (1996). Sardinia, cheese and modernization. In C. Levy (Ed.), Italian regionalism: History, identity and politics (pp. 81-106). Berg.

Crettiez, X. (1999). La question Corse. Éditions Complexe.

D’Anna, A. (2007). Corse et Sardaigne préhistoriques: Relations et échanges dans le contexte méditerranéen. Éditions du comité des travaux historiques et scientifiques (CTHS).

de la Calle, L., \& Fazi, A. (2010). Making nationalists out of Frenchmen? Sub-state nationalism in Corsica. Nationalism and Ethnic Politics, 16(3), 397-419.

DeLoughrey, E. (2007). Routes and roots: Navigating Caribbean and Pacific island literatures. University of Hawai'i Press.

DeLoughrey, E. (2001). The litany of islands, the rosary of archipelagoes: Caribbean \& Pacific archipelagraphy. Ariel: Review of International English Literature, 32(1), 21-51.

Donnan, H., \& Wilson, T.M. (2001). Borders: Frontiers of identity, nation, and state. Berg.

Farinelli, M.A. (2020). Managing the island territory: A historical perspective on sub-state nationalism in Corsica and Sardinia. Small States \& Territories, 3(1), 137-152.

Farinelli, M.A. (2017). Island societies and mainland nation-building in the Mediterranean: Sardinia and Corsica in Italian, French and Catalan nationalism. Island Studies Journal, 12(1), 21-34. https://doi.org/10.24043/isj.3

Giglioli, A. (2001). Italia e Francia 1936-39. Jouvence.

Hau'ofa, E. (2008). We are the ocean. University of Hawai'i Press.

Hau'ofa, E. (1993). Our sea of islands. In E. Waddell, V. Naidu, \& E. Hau'ofa (Eds.), A new Oceania: Rediscovering our sea of islands (pp. 2-16). University of the South Pacific.

Hayward, P. (2012). Aquapelagos and aqualpelagic assemblages: Towards an integrated study of is-land societies and maritime environments. Shima, 6(1), 1-11.

Hepburn, E. (2009). Explaining failure: The highs and lows of Sardinian nationalism. Regional and Federal Studies, 19(4-5), 595-618.

Hylland Eriksen, T. (1992). Us and them in modern societies. Ethnicity and nationalism in Trinidad, Mauritius and beyond. Scandinavian University Press.

INTERREG Marittimo-IT FR-Marittime (n. d.). Progetto programma INTERREG MarittimoIT FR-Marittime 2014-2020. Redazione dello studio finalizzato alla raccolta ed elaborazione dei dati secondo un prospetto comune per un'analisi e parresentazione "AS-IS" della portualità della Sardegna [Data on goods and passenger movements in Sardinian ports].

Knight, F.W. (1990). The Caribbean: The genesis of a fragmented nationalism. Oxford University Press.

Larousse. (n.d.). Archipel. Dictionnaire de Français. https://www.larousse.fr/dictionnaires/francais/archipel/5065?q=Archipel\#5039. 
La Préfet (1965, October 10). Le Préfet de la Corse à Monsieur le Ministre de l'Interieur [Memorandum of the Prefect to the Ministry of Internal Affairs about a voyage of Corsican MP's in Sardinia and Sicily]. Conseil Général. Rapport voyage en Sardaigne, [323 W 62]. ADCS, Ajaccio, Corsica.

Le Préfet (1968, February 8). Le Préfet de la Corse à Monsieur le Ministre de l'Interieur [Memorandum of the Prefect to the Ministry of Internal Affairs on the creation of a Corsican-Sardinian commision], Ministere de l'Interieur (MI 31483). AN, Pierfittesur-Seine.

Lilliu, G. (1987). La civiltà nuragica. Carlo Delfino.

Lilliu, G. (1971). La costante resistenziale sarda. Editrice Sarda Fossataro.

Mastino, A. (2005). Storia della Sardegna antica. Il Maestrale.

Maxia, M. (2008). Studi sardo-corsi: dialettologia e storia della lingua tra le due isole. Taphros.

Murgia, G. (1994). Contrabbando e ordine pubblico nella Gallura tra Blocco continentale e neutralità del regno di Sardegna (1800-1814). In A. Matone (Ed.), Studi e ricerche in onore di Girolamo Sotgiu (Vol. 2, pp. 9-35). CUEC.

Murgia, G. (1988). Il contrabbando tra la Sardegna e la Corsica. Études Corses, 16(30-31), 237-251.

Mari, N. (2016). Corse-Sardaigne: Une date symbolique, un accord historique et un espoir partagé. Corse Net Infos. https://www.corsenetinfos.corsica/Corse-Sardaigne-Unedate-symbolique-un-accord-historique-et-un-espoir-partage a20911.html

La Nuova Sardegna (2016). Il ministero ha deciso: Parco commissariato. La Nuova Sardegna. https://www.lanuovasardegna.it/olbia/cronaca/2016/11/13/news/il-ministero-hadeciso-parco-commissariato-1.14409346

La Nuova Sardegna (2013). Parco internazionale, le nomine di Bonanno fanno arrabbiare Comiti. La Nuova Sardegna.

https://www.lanuovasardegna.it/olbia/cronaca/2013/11/26/news/parcointernazionale-le-nomine-di-bonanno-fanno-arrabbiare-comiti-1.8188657

Olivesi, C. (1999). La cooperation inter-insulaire en Méditerranée. Le relations internationales des régions en Europe, 30(4), 745-762.

Oxford Dictionaries (2001). Archipelago. The New Oxford Dictionary of English. Oxford University Press.

Oostindie, G. (2006). Dependence and autonomy in sub-national island jurisdictions: The case of the Kingdom of the Netherlands. The Round Table, 95(386), 609-626. https://doi.org/10.1080/00358530600929792

Paci, D. (2015). Corsica fatal, Malta baluardo di romanità. L'irredentismo fascista nel mare nostrum. Le Monnier.

Paci, D. (2014). Is history the strongest weapon? Corsica in the Fascist mare nostrum. Journal of Modern Italian Studies, $19(5), \quad 625-640$. https://doi.org/10.1080/1354571X.2014.962259

Pais, E. (1923). Storia della Sardegna e della Corsica durante il dominio romano. Nardecchia.

Pigoreau, J. \& Ditrie, J. (1965). Le développement du tourisme en Sardaigne et en Corse. [Memorandum on tourism industry in Sardinia]. Conseil Général. Rapport voyage en Sardaigne, (323 W 62). ADCS, Ajaccio, Corsica. 
Pira, S. (1994). La Gallura nel settecento. Una repubblica montanara tra contrabbando e banditismo. In A. Mattone (Ed.), Studi e ricerche in onore di Girolamo Sotgiu (Vol. 2, pp. 91-105). CUEC.

Piredda, A. (1997). Lo stazzo e la Gallura. Profilo storico, sintesi e caratteri di una singolare civiltà. Gallizzi.

Prada, M. (1989). Table ronde sur les politiques d'accompagnement du développement économique et social de la Corse, rapport de Michel Prada.[Memorandum on Corsica's economy]. Tourisme; Cabinet et services rattachés; Cabinet; Directeur du Cabinet (19920517/25). AN, Pierfitte-sur-Seine.

Pugh, J. (2018). Relationality and island studies in the Anthropocene. Island Studies Journal, 13(2), 93-110. https://doi.org/10.24043/isj.48

Pugh, J. (2016). The relational turn in island geographies: Bringing together island, sea and ship relations and the case of the Landship. Social \& Cultural Geography, 17(8), 10401059. https://doi.org/10.1080/14649365.2016.1147064

Pugh, J. (2013). Island movements: Thinking with the archipelago. Island Studies Journal, 8(1), 9-24.

Racheli, G. (1982). L'Arcipelago della Maddalena nella Storia. Vert Sardegna.

Rainero, R.H. (2005). Aspetti e problemi delle relzioni tra l'Italia e la Francia. Unicopli.

Ravis-Giordani, G. (1983). Bergers corses. Les communautés villageoises du Niolu. Édisud.

Regione Autonoma della Sardegna (RAS). (2016). Rapporti Sardegna-Corsica, Pigliaru ed assessori ad Ajaccio per visita istituzionale: rafforzare relazioni tra le due isole. Notizie. http://www.regione.sardegna.it $/ \mathrm{j} / \mathrm{v} / 25$ ? $\mathrm{s}=303612 \& \mathrm{v}=2 \& \mathrm{c}=6578 \& \mathrm{t}=1$

Regione Autonoma della Sardegna (RAS) (1954-1968). Statistica della navigazione marittima nei porti Sardi.

Rombaldi, J. (1887). La Corse française au XVIe siècle. Sampiero Corso, colonel générale de l'infanterie corse au service de la France. Émile Lechevalier.

Roux, C. (2012). From the Great War to democracy: Former combatants and the Sardinian Autonomist Movement. In N. Duclos (Ed.), War veterans in postwar situations: Chechnya, Serbia, Turkey, Peru and Côte d'Ivoire (pp. 201-217). Palgrave Macmillan.

Royle, S.A., \& Brinklow, L. (2018). Definitions and typologies. In G. Baldacchino (Ed.), The Routledge international handbook of island studies (pp. 3-20). Routledge.

Sahlins, P. (1989). Boundaries: The making of France and Spain in the Pyrenees. University of California Press.

Shorrock, W.I. (1983). The Tunisian question in French policy toward Italy, 1881-1940. The International Journal of African Studies, 16(4), 631-651.

SISDE (1983, March 8). Trasmissione di appunto riservato [intelligence report on the contacts between Sardinian and Corsican nationalists]. MI, Dipartimento di P.S., Segreteria del Dipartimento, Ufficio di Ordine Pubblico, G, Associazioni 1966-1986 (busta 344, fascicolo 65/42/55, Movimenti Indipendentisti Sardi, sottofascicolo Movimento Rivoluzionario Separatista Sardo, prot. no. 2/4826).

Sole, C. (1959) Sovranità e giurisdizione sulle isole intermedie (1767-1793). CEDAM.

Sole, C. (1955-1956). Aspetti economici e politici del contrabbando tra la Sardegna e la Corsica nel XVIII secolo. Studi Sardi, 18, 180-244. 
Sorgente, B., Sorgente, R., Olita, A., Fazioli, L., Cucco, A., Perilli, A., Sinerchia, M., \& Ribotti, A. (2012). Effects of protection rules and measures in an important international strait area: The Bonifacio Strait. Journal of Operational Oceanography, 5(1), 35-44.

Stratford, E., Baldacchino, G., MacMahon, E., Farbotko, C., \& Harwood, A. (2011). Envisioning the archipelago. Island Studies Journal, 6(2), 113-130.

Toso, F. (2008). Aspetti del bonifacino in diacronia. Bollettino di Studi Sardi, 1, 147-177.

Treccani. (n.d). Archipelago. Vocabolario. http://www.treccani.it/vocabolario/arcipelago/

Vardabasso, G. (1939). La struttura geologica della Corsica. Tipografia F.lli G. \& M. Melis Schirru.

Veenendaal, W.P. (2015). The Dutch Caribbean municipalities in comparative perspective. Island Studies Journal, 10(1), 15-30.

Warrington, E., \& Milne, D. (2018). Governance. In G. Baldacchino (Ed.), The Routledge international handbook of island studies (pp. 173-201). Routledge.

Xie, B., Zhu, X., \& Grydehøj, A. (2020). Perceiving the Silk Road Archipelago: Archipelagic relations within the ancient and 21st Century Maritime Silk Road. Island Studies Journal, 15(2), 55-72. https://doi.org/10.24043/isj.118 